Life Sciences Contributions

Royal Ontario Museum

Morphology of the Basisphenoid Pits and Related Structures of the Bat Otomops martiensseni (Chiroptera: Molossidae)
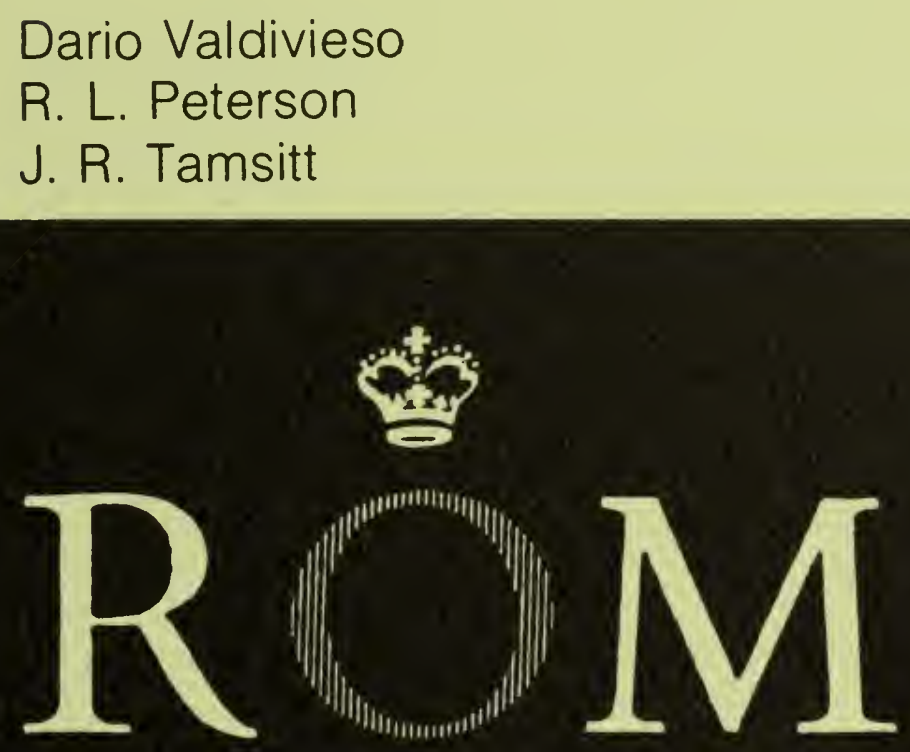


\section{ROYAL ONTARIO MUSEUM LIFE SCIENCES PUBLICATIONS INSTRUCTIONS TO AUTHORS}

Authors are to prepare their manuscripts carefully according to the following instructions. Failure to do so will result in the manuscript's being returned to the author for revision. All manuscripts are considered on the understanding that if accepted they will not be offered for publication elsewhere.

1. GENERAL Papers for publication are accepted from ROM staff members, Research Associates, or from researchers reporting on work done with ROM collections. In exceptional cases, monographic works on the flora and/or fauna of Ontario will be considered for publication by authors not affiliated with the ROM. Authors are expected to write clearly and concisely, and to omit all material not essential for an understanding of the main theme of the paper.

2. FORMAT Manuscripts are to be typed double-spaced (including captions, synonomies, literature cited, and tables) on 11 " $\times 8 \frac{1}{2}$ " paper with a $1 \frac{1}{2}$ " margin on all sides. Three xerox copies are to be submitted to the Chairman of the Editorial Board, and the original retained by the author(s). A separate sheet is to be submitted giving author(s) names, affiliation, title of publication, series in which it is to appear, number of typed pages, number of tables, and number of figures. Manuscripts should normally be organized in the following order: Table of Contents, Abstract, Introduction, Materials and Methods, Results, Discussion, Conclusions, Summary (if paper is long), Acknowledgements, Literature Cited, and Appendices. Authors are encouraged to include foreign language translations of the Summary where appropriate. Headings of sections are to be left-justified to the text margin. The first line of the first paragraph in each new section should not be indented. Text-figures are referred to as "Fig. 1". Literature cited in the text is in the form "Jones (1972)" or "(Jones, 1972)" or "(Smith, 1960:71-79, fig. 17)",

3. STANDARD SOURCES The primary source for decisions on format and style is A Guide for Contributors and Editors of ROM Life Sciences Publications, available from the Chairman of the Editorial Board. Otherwise, consult CBE (AIBS) Style Manual (3rd Edition). Other standard sources are as follows: for English spelling (Concise Oxford Dictionary), for Canadian place names and coordinates (Gazetteer of Canada), and for spelling of geographic names (Times [London] Atlas).

4. ABSTRACT All papers are preceded by a short and factual abstract, about 3 per cent as long as the text, but not longer than 400 words. The abstract is to be followed by four to six keywords enclosed in brackets.

5. TAXONOMY The name of a taxon is given in full in headings, where it appears for the first time, or when the name begins a paragraph. Use authority and date if appropriate, with first mention of each taxon and not thereafter. Taxonomic papers follow the layout in Life Sciences Contribution 99, particularly the synonomies.

6. LITERA TURE CITED References in the text cite author and date and are enclosed in parentheses (Smith, 1978). Complete references are listed in alphabetical order by author at the end of the paper. When there are two or more citations for an author, the works are listed chronologically. Names of journals are not abbreviated. Consult Life Sciences Contributions beginning with 117 for correct bibliographic form.

7. TABLES All tables are numbered consecutively in arabic numerals in numerical order of their first mention in the text. Mark the appropriate text location of each table with a marginal notation. Each table is typed on a separate sheet. Avoid footnotes etc., to tables by building them into the title.

8. FIGURES All figures are numbered consecutively in arabic numerals. Component photographs or drawings are labelled sequentially in upper case letters. Mark the appropriate text location of each figure with a marginal notation. The intended reduction for figures is ideally one and a half to two times. All labelling on figures is in blue pencil and not inked or letraset. Halftones must be photographic prints of high contrast on glossy paper. Authors are to submit $10^{\prime \prime} \times 8$ " copies with the MS and retain originals until they are requested. Figure captions are to appear grouped together on a separate page at the end of the MS. 
DARIO VALDIVIESO Morphology of the Basisphenoid
R. L. PETERSON

J. R. TAMSITT Pits and Related Structures of the Bat Otomops martiensseni (Chiroptera: Molossidae) 


\section{ROYAL ONTARIO MUSEUM PUBLICATIONS IN LIFE SCIENCES}

The Royal Ontario Museum publishes three series in the Life Sciences:

LIFE SCIENCES CONTRIBUTIONS, a numbered series of original scientific publications including monographic works.

LIFE SCIENCES OCCASIONAL PAPERS, a numbered series of original scientific publications, primarily short and usually of taxonomic significance.

LIFE SCIENCES MISCELLANEOUS PUBLICATIONS, an unnumbered series of publications of varied subject matter and format

All manuscripts considered for publication are subject to the scrutiny and editorial policies of the Life Sciences Editorial Board, and to review by persons outside the Museum staff who are authorities in the particular field involved.

\section{LIFE SCIENCES EDITORIAL BOARD}

Senior Editor: J. H. MCANDREWS

Editor: R. D. JAMES

Editor: C. MCGOWAN

DARIO VALDIVIESO is a Research Associate in the Department of Mammalogy, Royal Ontario Museum.

R. L. PETERSON is Curator in the Department of Mammalogy, Royal Ontario Museum, and Professor in the Department of Zoology, University of Toronto.

J. R. TAMSITT is Curator in the Department of Mammalogy, Royal Ontario Museum, and Associate Professor in the Department of Zoology, University of Toronto.

Canadian Cataloguing in Publication Data

Valdivieso, Dario, 1936-

Morphology of the basisphenoid pits and related structures of the bat Otomops martiensseni

(Chiroptera: Molossidae)

(Life sciences contributions; no. 119 ISSN 0384-8159)

Bibliography: $p$.

ISBN 0-88854-238-0 pa.

1. Bats - Anatomy. I. Peterson, Randolph L., 1920

Il. Tamsitt, J.R., 1928- III. Royal Ontario

Museum. IV. Title. V. Series.

QL737.C54V35 599'.4'0448 C79-094513-4

Publication date: 29 June 1979

ISBN 0-88854-238-0

ISSN 0384-8159

(C) The Royal Ontario Museum, 1979

100 Queen's Park, Toronto, Canada M5S 2C6

PRINTED AND BOUND IN CANADA AT THE ALGER PRESS 


\title{
Morphology of the Basisphenoid Pits and Related Structures of the Bat Otomops martiensseni (Chiroptera: Molossidae)
}

\begin{abstract}
The morphology and histology of the basisphenoid pits were studied in the bat Otomops martiensseni (Chiroptera: Molossidae). The pits are deep and well-defined bony cavities located posteriorly in the nasal pharynx. They are juxtaposed to the opening between the nasal and laryngeal pharynges and anatomically communicate with the middle ear through the auditory tube. Basisphenoid pits may function as resonating chambers for sound waves emitted by the larynx, but experimental research is needed to determine their importance in the sonar system.
\end{abstract}

(basisphenoid pits; morphology and histology; Otomops martiensseni; Molossidae; Chiroptera)

\section{Introduction}

Literature concerning the anatomy of the ear of Chiroptera is considerable (Henson, 1961, 1970; Novick, 1977), but few works deal specifically with basisphenoid pits, which are paired depressions in the basisphenoid bone anteromedial to the auditory bullae that have been postulated to be associated with echolocation in certain bats (Peterson, 1969). Basisphenoid pits are present in insectivorous bats of the families Emballonuridae, Vespertilionidae, and Molossidae (G. S. Miller, 1907), but the variation in size of pits is the greatest in molossid bats, a group which is circumtropical in distribution (Walker, 1975) and in which echolocation is highly developed (Griffin, 1958). Furthermore, after a preliminary review of many species of free-tailed or mastiff bats of the family Molossidae by one of us (RLP), a general correlation appears to exist between the development of the pits and the size and complexity of the external ears. Such small, simple-eared bats as the flat-headed bats of the genera Platymops and Sauromys have the least developed basisphenoid pits (Peterson, 1965), and species with larger, complex external ears have the most developed pits, as in the big-eared mastiff bats of the genus Otomops (Peterson, 1969).

We describe here the morphology, histology, and variation in size of the basisphenoid pits in Otomops martiensseni (Matschie) of the family Molossidae. Objectives are to describe the relationships of the pits to associated structures and to attempt to correlate morphology with function in the sonar system. 
Otomops martiensseni was chosen because the basisphenoid pits are the largest of any molossid bat (Peterson, 1969). This species, which belongs to one of the most distinctive genera of the family, is also characterized by large size (forearm length of 47 adults, $63-73 \mathrm{~mm}$ ), exceptionally large external ears (length in 39 adults, 33-43 $\mathrm{mm}$ ) that are conjoined on an extended snout, and by the absence of the tragus and antitragus. O. martiensseni occurs in southern, central, and eastern Africa north to Kenya (Meester and Setzer, 1971); southern Ethiopia (Largen et al., 1974); and the Republic of Djibouti (Hill and Morris, 1971). Other taxa of Otomops occur in the Malagasy Republic ( $O$. madagascariensis), India ( $O$. wroughtoni), Java $(O$. formosus), and New Guinea (O. papuensis and $O$. secundus).

\section{Materials and Methods}

All specimens studied were from Kenya. Heads of nine preserved specimens of $O$. martiensseni were dissected for studies of gross morphology. Seven heads were sectioned, but only three were suitable for histological study. In addition, basisphenoid pits were examined and measured in skulls of 47 adults. All specimens examined are in the collections of the Department of Mammalogy, Royal Ontario Museum. The nomenclature of osseous structures and organs follows M. E. Miller (1962) and Henson (1970), and that of tissues follows di Fiore (1963).

\section{Histological Methods}

Techniques for preparation of osseous structures for histological study were those of Luna (1968) with certain modifications. Specimens were fixed in Bouin's or preserved in formalin and stored in 65 per cent alcohol for one or more years. Before processing, the tongue, the mandible, and the skin of the head were removed, and, if fixed in formalin, the specimen was washed and placed in several changes of Bouin's for 2 weeks or longer. Heads were decalcified in 1 per cent nitric acid (in 80 per cent ethanol) for 7 days, during which time the solution was changed daily. Specimens were then washed for 4 hours in running tap water, dehydrated in 50,70, 90, and 100 per cent ethanol for 24 -hour periods, and then cleared for 4 hours in chloroform (one change after 2 hours).

Conventional double-embedding procedures were not successful, and, after experimentation, the following method was found to be effective. Entire heads were placed in methyl benzoate in a vacuum oven maintained at $58^{\circ} \mathrm{C}$ for 24 hours. They were then placed successively for 24-hour periods in 2, 4, and 6 per cent celloidin in methyl benzoate and for 1 week in 8 per cent celloidin-methyl benzoate. Heads were then transferred to pure benzene for 48 hours (one change at 24 hours), to a 1:1 solution of benzene-paraffin for 24 hours, and then placed in pure paraffin for 24 hours. Transverse and sagittal sections with tissues in situ were cut serially on a rotary microtome at $15 \mu \mathrm{m}$, and staining was with Harris haematoxylin and eosin. Sections were photographed through a Reichert Zetophan photomicroscope. When studying the photomicrographs it should be kept in mind that the above procedure is a harsh one and inevitably causes distortion. Measurements given (to $0.1 \mathrm{~mm}$ ) therefore do not necessarily reflect the sections' true dimensions in life. 


\section{Measurements and Statistical Analyses of Cranial Characters}

Measurements (in millimetres) were of the right side of the skull to avoid bias attributable to asymmetry. Measurements were taken to the nearest 0.01 by a bi-coordinate digitizer with a Wild M5 binocular stereomicroscope (Wild of Canada Ltd., Mississauga, Ontario) adapted for an automatic Model PDP-8 Digitizing System (designed by Ruscom Logics Ltd., Downsview, Ontario). Special details of a system comparable to that used here and procedures for measurements were given by Anderson (1972).

Characters measured were the length of basisphenoid pits (greatest straight-line distance between the anterior and posterior margins of the pit measured on its long axis), width of the pits (greatest straight-line distance between the medial and lateral margins of the pit), and width of the septum between the basisphenoid pits (straight-line distance at the midpoint between the lateral margins of the septum).

Specimens were sorted by sex for statistical analyses. Mean and standard error were calculated for each character, and differences between the sexes were examined using Student's $t$-tests (Sokal and Rohlf, 1969).

\section{Specimens Examined}

Specimens studied are adults unless indicated otherwise. Those sectioned were two males and a female from Mount Suswa, Kedong Valley, Rift Valley $\left(01^{\circ} 10^{\prime} \mathrm{S}, 36^{\circ}\right.$ $20^{\prime}$ E). In addition, four males and a female from Mount Suswa, Kedong Valley, Rift Valley; one juvenile male and two females from Lake Naivasha, Rift Valley $\left(01^{\circ} 10^{\prime}\right.$ $\left.\mathrm{S}, 36^{\circ} 21^{\prime} \mathrm{E}\right)$; and a female from Koboko, Ithundu Caves $\left(02^{\circ} 12^{\prime} \mathrm{S}, 37^{\circ} 43^{\prime} \mathrm{E}\right)$ were dissected for studies of gross morphology.

Measurements of the basisphenoid pits were taken in 47 skulls from the following localities: two males and three females, Ithundu Caves; 11 males and seven females from $19 \mathrm{~km} \mathrm{~W}$ Makindu $\left(02^{\circ} 18^{\prime} \mathrm{S}, 38^{\circ} 00^{\prime} \mathrm{E}\right)$; six males and 11 females from Mount Suswa, Kedong Valley, Rift Valley; and seven females from Lake Baringo, Kampi ya Moto $\left(00^{\circ} 11^{\prime} \mathrm{S}, 35^{\circ} 52^{\prime} \mathrm{E}\right)$.

\section{Abbreviations Used in the Figures}

\begin{tabular}{|c|c|c|c|}
\hline AT & auditory tube & NPH & nasal pharynx \\
\hline BS & basisphenoid bone & OAT & orifice of auditory tube \\
\hline BSP & basisphenoid pit & $\mathrm{OC}$ & oral cavity \\
\hline E & epiglottis & OLPH & opening of laryngeal pharynx \\
\hline ES & esophagus & SBSP & mesial septum separating \\
\hline $\mathrm{L}$ & larynx & & basisphenoid pits \\
\hline LPH & laryngeal pharynx & SP & soft palate \\
\hline M & malleus & SSE & stratified squamous epithelium \\
\hline ME & middle ear cavity & TB & tympanic bone \\
\hline MF & mandibular fossa & TM & tympanic membrane \\
\hline NP & nasal passage & TT & tensor tympani muscle \\
\hline
\end{tabular}


In crania of $O$. martiensseni the basisphenoid pits are large (about $3.0 \mathrm{~mm}$ long and $1.5 \mathrm{~mm}$ wide) and deep with overhanging edges which are pronounced posteriorly and posterolaterally. They are divided by a septum which is broad anteriorly but becomes narrow as it tapers posteriorly (Fig. 1). The pits are deep posteriorly $(1.5-1.6 \mathrm{~mm})$ and become shallow $(1.0-1.2 \mathrm{~mm})$ towards the anterior margins (Fig. 2). The large tympanic bone, which is elongated and projects forward to touch the pterygoid bone anteromedially, covers the posterolateral margin of each pit and terminates as a broad, lobular structure (Fig. 1). In a transverse plane the pits are located about midway between the foramina ovale and the mandibular fossae.

When the pharyngeal region of $O$. martiensseni is studied macroscopically (Figs. 2,3 ), the basisphenoid pits are partially covered by the soft palate and are located immediately dorsal to the opening of the laryngeal pharynx (Figs. 3A-C, 4A). This opening, which is $1.5 \mathrm{~mm}$ wide and $2.0 \mathrm{~mm}$ long, is dorsal to the epiglottis of the larynx and proximal to the opening of the esophagus (Fig. 4B). The folds of the epiglottis (Fig. 4C) are shaped to fit into the lips of the opening of the laryngeal pharynx (Figs. 3B, C), and the two structures are juxtaposed (Figs. 2, 3C). Moreover, the opening of the nasal pharynx is continuous with the cavities of the basisphenoid pits.

The basisphenoid pits are cancellous, bony cavities (Figs. 5A-D, 6A-D). The ground substance of the bone is deeply stained by eosin, and immediately internal to it is a layer of loose connective tissue containing large adipose cells 28 to $30 \mu \mathrm{m}$ in diameter with eccentrically placed nuclei. Cells in this layer are irregular in shape, and also present are many lymphocytes and numerous, larger polymophonuclear leucocytes. This layer is highly vascularized, and throughout it numerous small blood vessels occur, some of which are capillaries. Others are venules surrounded by a condensation of connective tissue, and some are arterioles with smooth muscle fibres surrounding the endothelium which forms a wall equal in thickness to that of the lumen. This layer, which varies in thickness from 40 to $50 \mu \mathrm{m}$, is thickest at the posterior and anterior ends of the pits, dorsal and proximal to the mesial septum, and immediately dorsal to areas where the osseous edges project medially from the lateral walls of the pits.

Internal to this layer is a layer of numerous cartilage cells as well as many elastic fibres. This stratum varies in thickness from 25 to $40 \mu \mathrm{m}$ and also contains numerous mucous glands and lymphatic nodules.

The most internal layer of the pits is thin $(10-20 \mu \mathrm{m})$ and is also the most well defined of those layers lining the pits. It consists of a pseudostratified, ciliated, columnar epithelium. The nuclei of these cells are large $(8-12 \mu \mathrm{m})$ and touch the basal membrane. In regions of the basisphenoid pits where the osseous portion of the edges terminates ventromedially and is continuous with the soft palate, columnar epithelium lines the pits but is covered externally by a layer of dense connective tissue (10-15 $\mu \mathrm{m}$ wide). In the soft palate this dense connective tissue replaces the loose connective tissue that lines the osseous portions of the pits. In the region of the auditory tube, as it passes through the soft palate and opens into the lumen of the pits (Figs. 6B, C), the mucosa lining the auditory tube is separated from the lining of the pits by a thick $(0.4-0.5 \mathrm{~mm})$ layer of loose connective tissue, lymphatic nodules, and numerous mucous glands. 


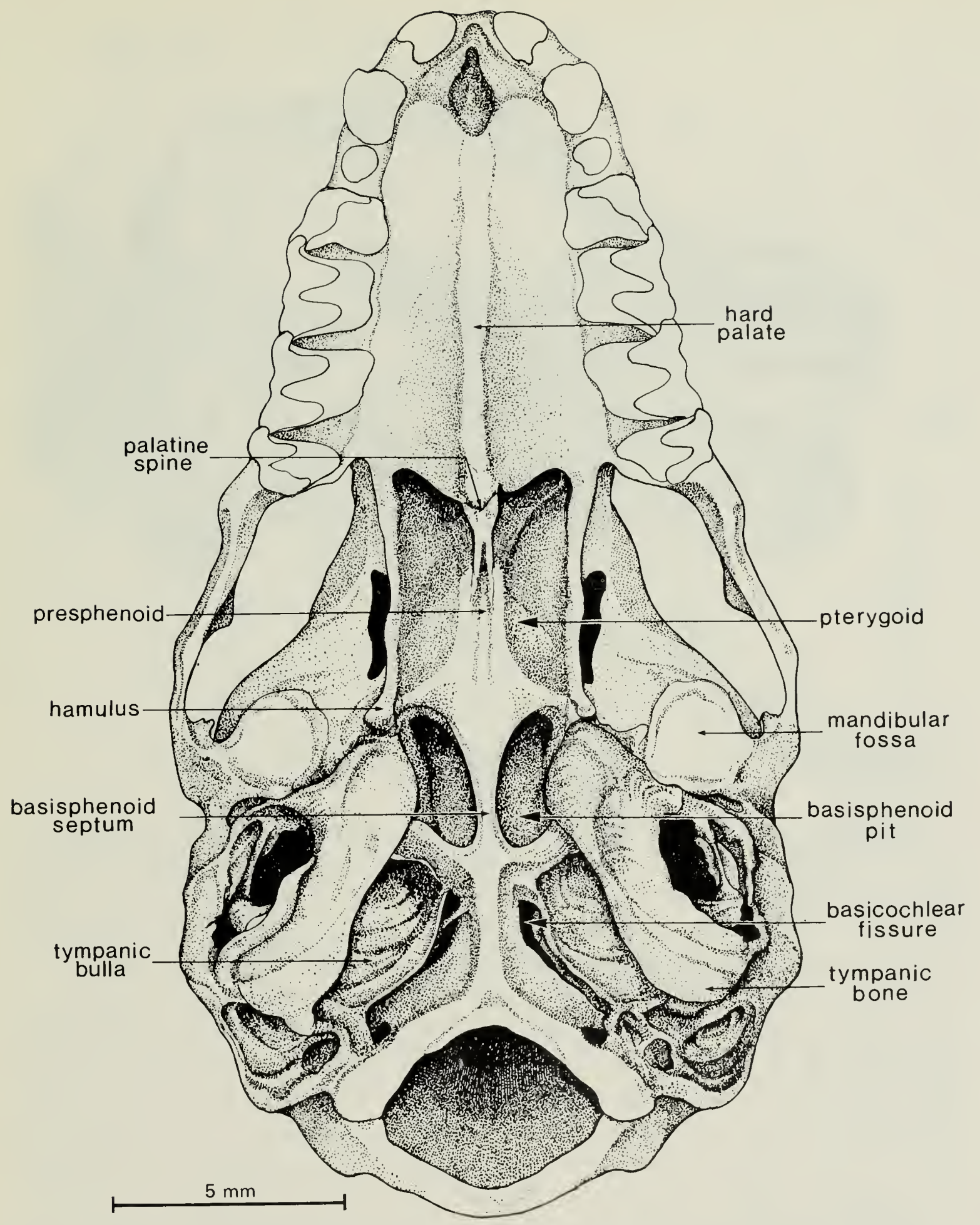

Fig. 1 Ventral view of skull of Otomops martiensseni ROM 41923, adult female.

The osseous portion of the mesial septum of the pits is covered by a pseudostratified, ciliated, columnar epithelium continuous with that which lines the pits. In the pharyngeal region, however, the ventral part of the septum is covered by a thin layer $(40-45 \mu \mathrm{m})$ of striated muscle, external to which are loose connective tissue, hyaline cartilage, and mixed glands. In the region of the orifice of the auditory tube, the ventral tip of the septum bears mostly glandular tissue, and anteriorly, as the ventral portion of the septum expands and the pits diminish in size, the osseous component predominates and bears only a few glands distally. 


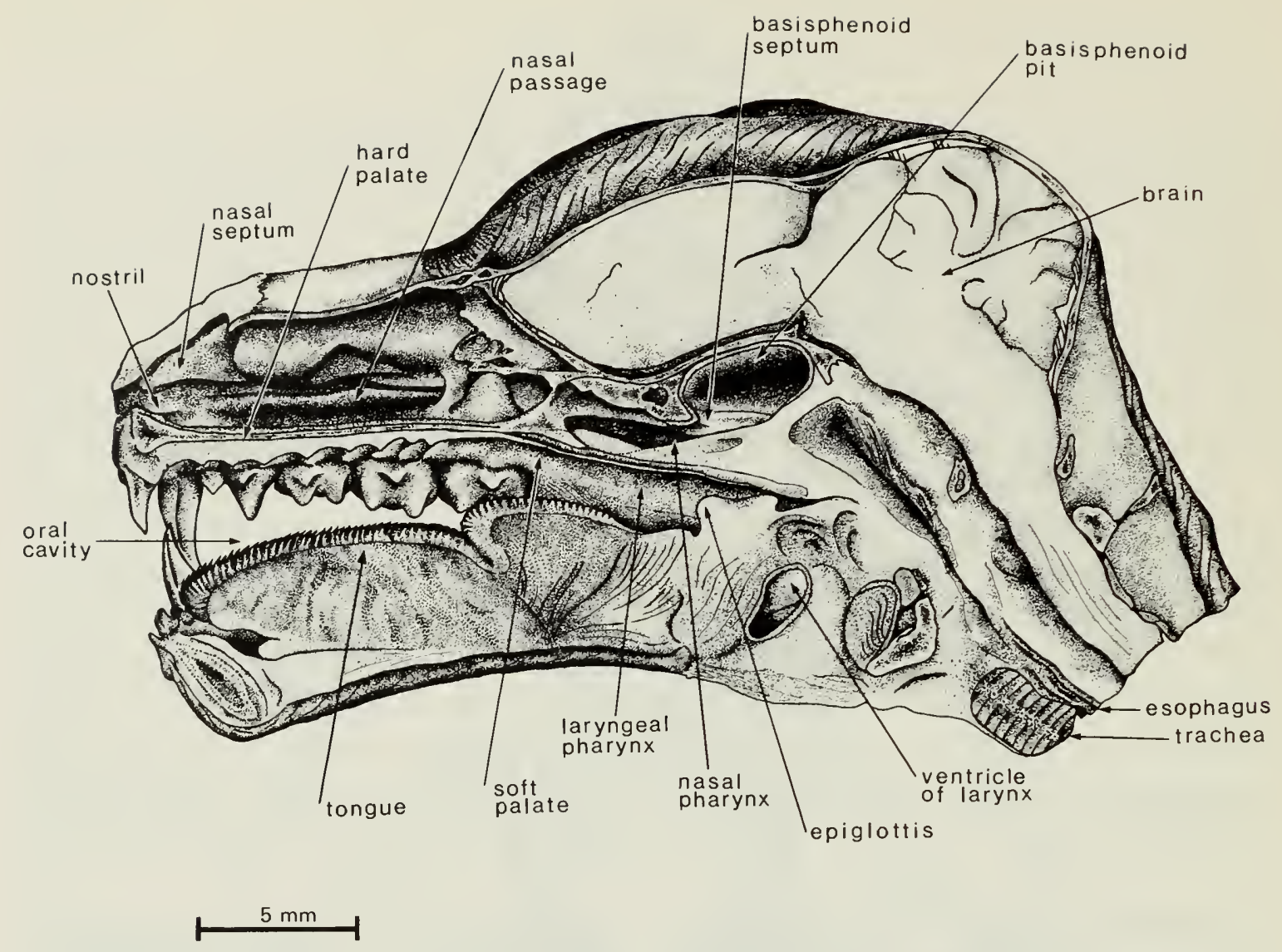

Fig. 2 Parasagittal section of the head of Otomops martiensseni ROM 45945, adult male.

The large middle ear or tympanic cavity is lined with a membrane consisting of a thin layer (25-40 $\mu \mathrm{m}$ wide) of connective tissue covered with simple cuboidal epithelium. Epithelial cells are cuboidal or columnar, with nuclei in two or more rows, and cilia are widely distributed in all areas of the cavity. Small mucous glands are infrequently present, and capillaries are numerous in the connective tissue.

The large tensor tympani muscle, the only middle ear muscle studied, originates on the ventral surface of the ventrolateral edge of the basisphenoid pit immediately posterior to the pharynx and then passes ventrally to the ventrolateral edge of the pit (Figs. 5B-D), where it reaches maximum size $(2.0 \mathrm{~mm}$ wide and $1.5 \mathrm{~mm}$ thick). Posteriorly the muscle decreases in size, passes ventrolaterally to the cochlear wall (Fig. 5A), and crosses the cavity of the middle ear before inserting on the malleus.

The auditory or Eustachian tube is large $(2 \mathrm{~mm}$ long and $4 \mathrm{~mm}$ wide at its greatest diameter) and anteriorly fills most of the space of the tympanic bone (Figs. 6A-C). It is almost completely surrounded by the tympanic bone throughout most of its distance and is partially surrounded by cartilage in the pharyngeal region. The lining consists of fibrillar connective tissue, external to which is ciliated, columnar epithelium

Fig. 3 Transverse sections through the pharyngeal region of Otomops martiensseni ROM 41912, adult female.

A Entire head showing relationship of nasal pharynx, laryngeal pharynx, and basisphenoid bone.

B Section slightly posterior to that in A, showing basisphenoid pits and opening of laryngeal pharynx.

C Section slightly posterior to that in $\mathrm{B}$, enlarged and in greater detail to illustrate juxtaposition of basisphenoid pits to epiglottis and larynx. 


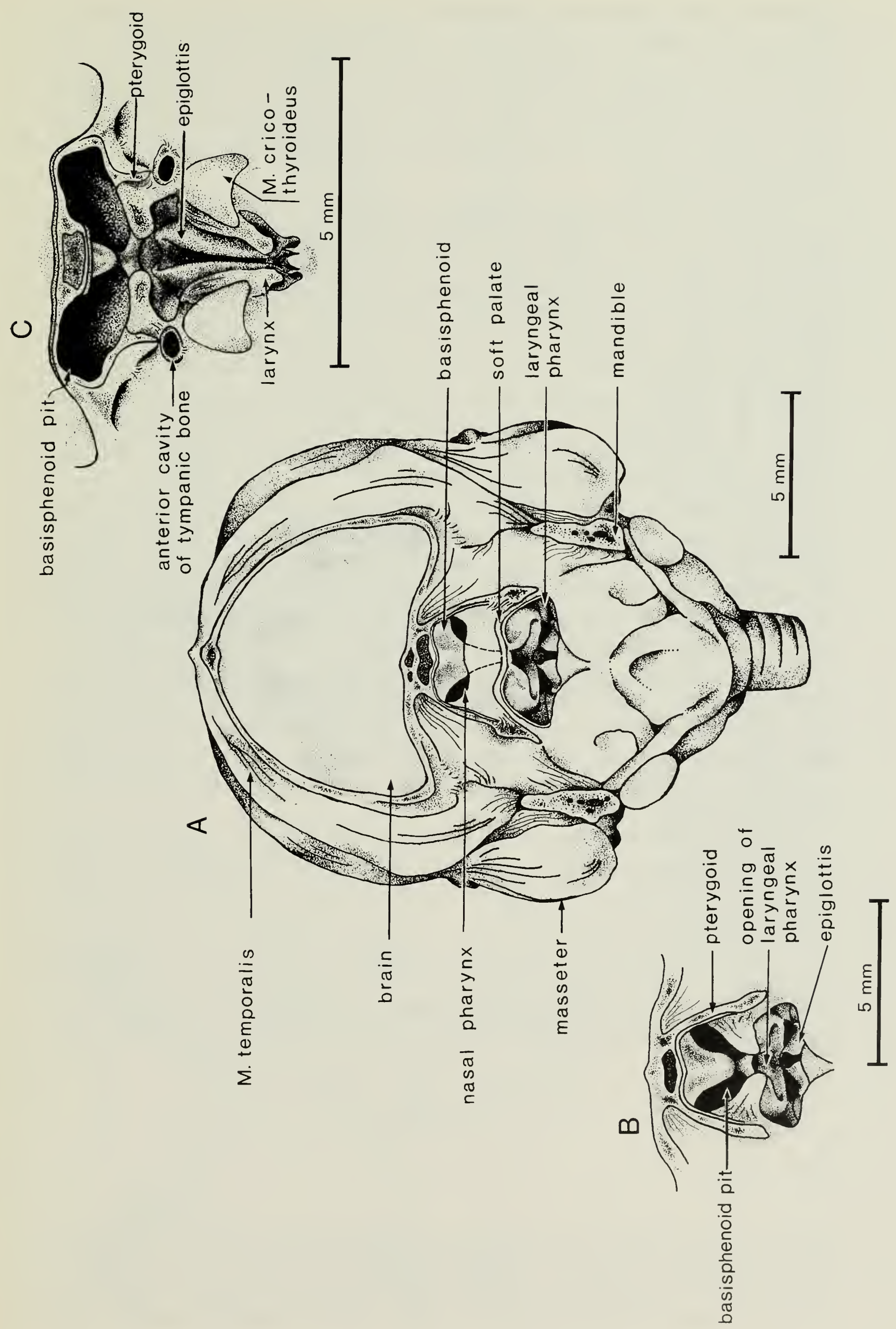


(20-40 $\mu \mathrm{m}$ wide) which becomes stratified in the region of the pharynx. Glands are absent in the posterior osseous region, and the lining adheres closely to the surrounding bone. In the cartilaginous part towards the pharynx, the lining or mucosa becomes thicker dorsally (50-70 $\mu \mathrm{m}$ wide) and contains many mixed glands. Cilia are randomly dispersed but occur throughout the tube. Lymphocytes are numerous in the surrounding connective tissue, and nodules are formed in the region proximal to the orifice of the tube.

The orifice of the auditory tube ( $70-80 \mu \mathrm{m}$ wide) opens through the soft palate into the basisphenoid pit in the pharyngeal region (Fig. 6C). As the auditory tube narrows (50-60 $\mu \mathrm{m}$ wide) towards the orifice, the tube has two diverticula and is surrounded by hyaline cartilage, which unites laterally with the osseous portion of the lateral rim of the pit. In this region the auditory tube is lined with stratified, columnar epithelium (20-25 $\mu \mathrm{m}$ wide). The orifice, which opens into the lumen of the pit proximal to the most medial projection of the osseous edge of the pits (Fig. 6C), is not surrounded by cartilage but by loose connective tissue, glandular tissue, blood vessels, and striated muscle. At the juncture of the orifice with the lumen of the pit, the epithelium changes from stratified columnar to the pseudostratified, ciliated, columnar epithelium that characteristically lines the pits.

The walls of the larynx are cartilages bound together by two thick connective tissue membranes, and the lining of the cavity is a mucous membrane. The $M$. cricothyroideus forms the bulk of the muscle surrounding the laryngeal cartilages. The epiglottis is a cartilaginous plate (Figs. 3B, 4C), and the perichondrium of this structure is continuous with the lamina propria of the mucous membrane and with a layer of stratified, squamous epithelium. The shape of the pharynx is conical (Fig. $6 \mathrm{C})$. The nasal pharynx is lined with columnar, ciliated epithelium, and the laryngeal or oral pharynx is lined by stratified, squamous, nonkeratinizing epithelium. The pharyngeal epithelium lies on a thick, connective tissue membrane with many elastic fibres and less numerous collagenous fibres. Internally, a thick layer of striated muscle with several mixed glands and a fibrous layer connects the pharynx (Figs. 6C, D) with adjacent structures.

Dimensions of the basisphenoid pits in 19 male and 28 female $O$. martiensseni did not differ significantly. Means and standard errors of the length of the pit of males and females were, respectively, $2.89 \pm 0.047$ and $2.86 \pm 0.048\left(P_{\mathrm{t}}=>0.05 \mathrm{~ns}\right)$, and those of the width were, respectively, $1.54 \pm 0.023$ and $1.52 \pm 0.019\left(P_{\mathrm{t}}=0.84\right.$ ns). Width of the mesial septum separating the pits, however, was significantly smaller $\left(P_{\mathrm{t}}=<0.03\right)$ in females $(0.63 \pm 0.010)$ than in males $(0.65 \pm 0.011)$. In both sexes, however, the position of the pits was identical, that is, centred at a level slightly posterior to the most anterior projections of the mandibular fossae (Fig. 1).

\section{Discussion}

Except for an increase in surface area due to the presence of basisphenoid pits, the histological pattern of tissues in the pharyngeal region of Otomops martiensseni is not unlike that of other mammals. Nonetheless, the presence of basisphenoid pits in this and other species of Microchiroptera is unique, and such related structures as the 

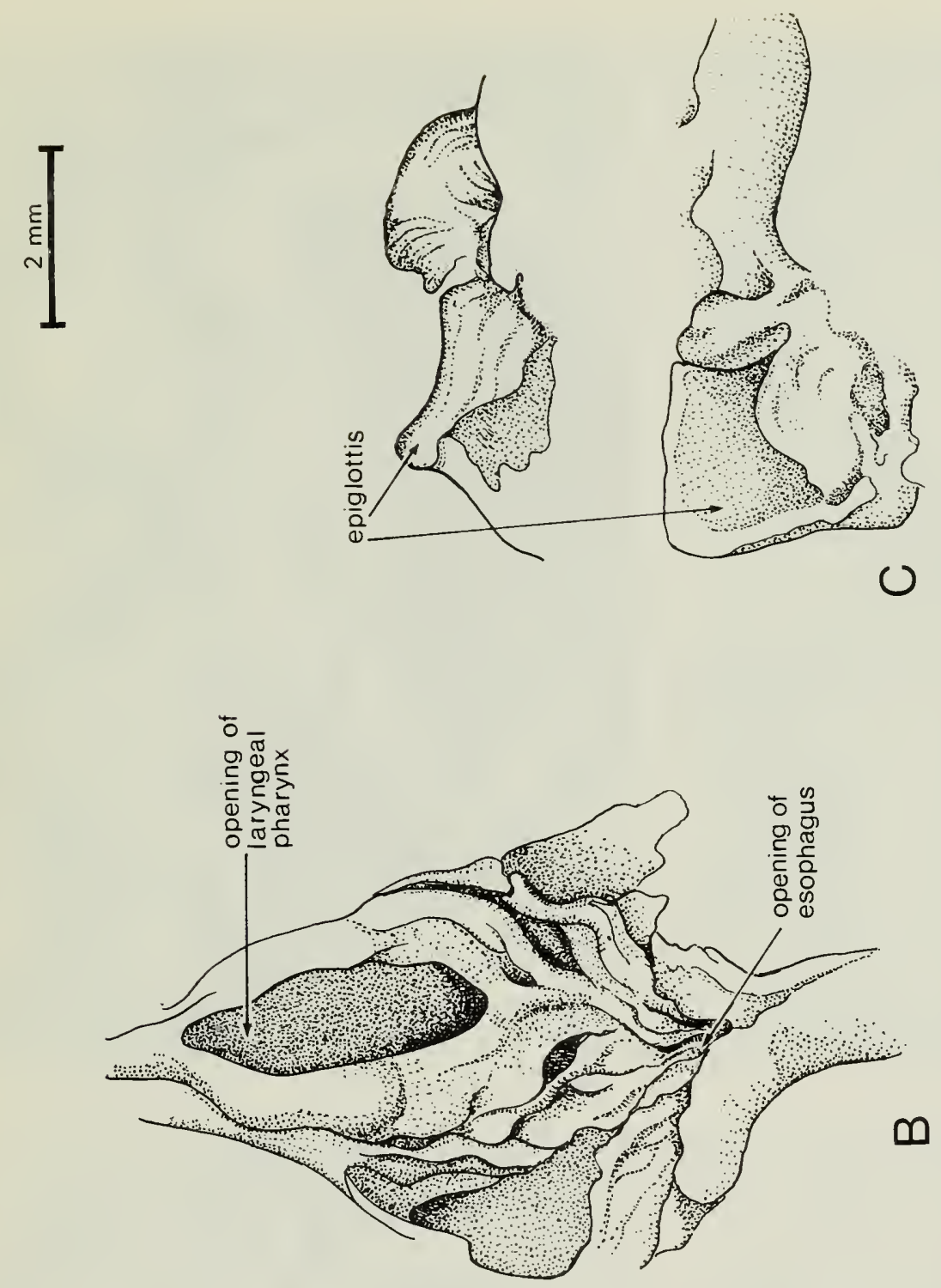

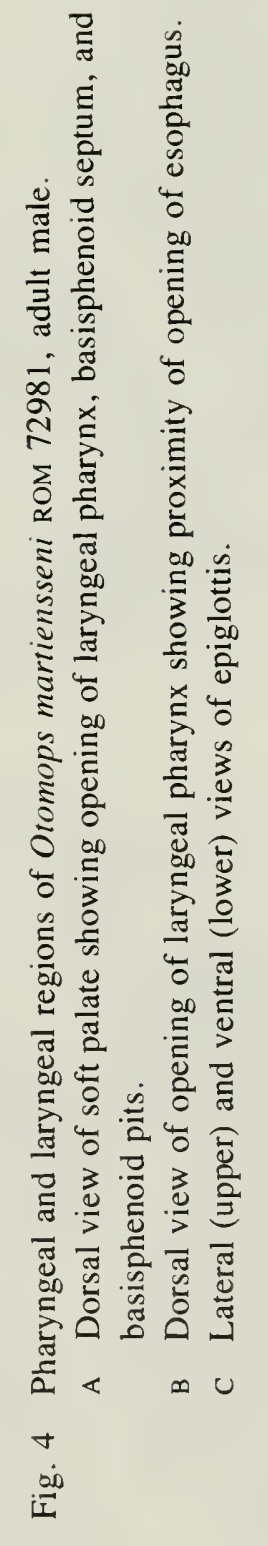

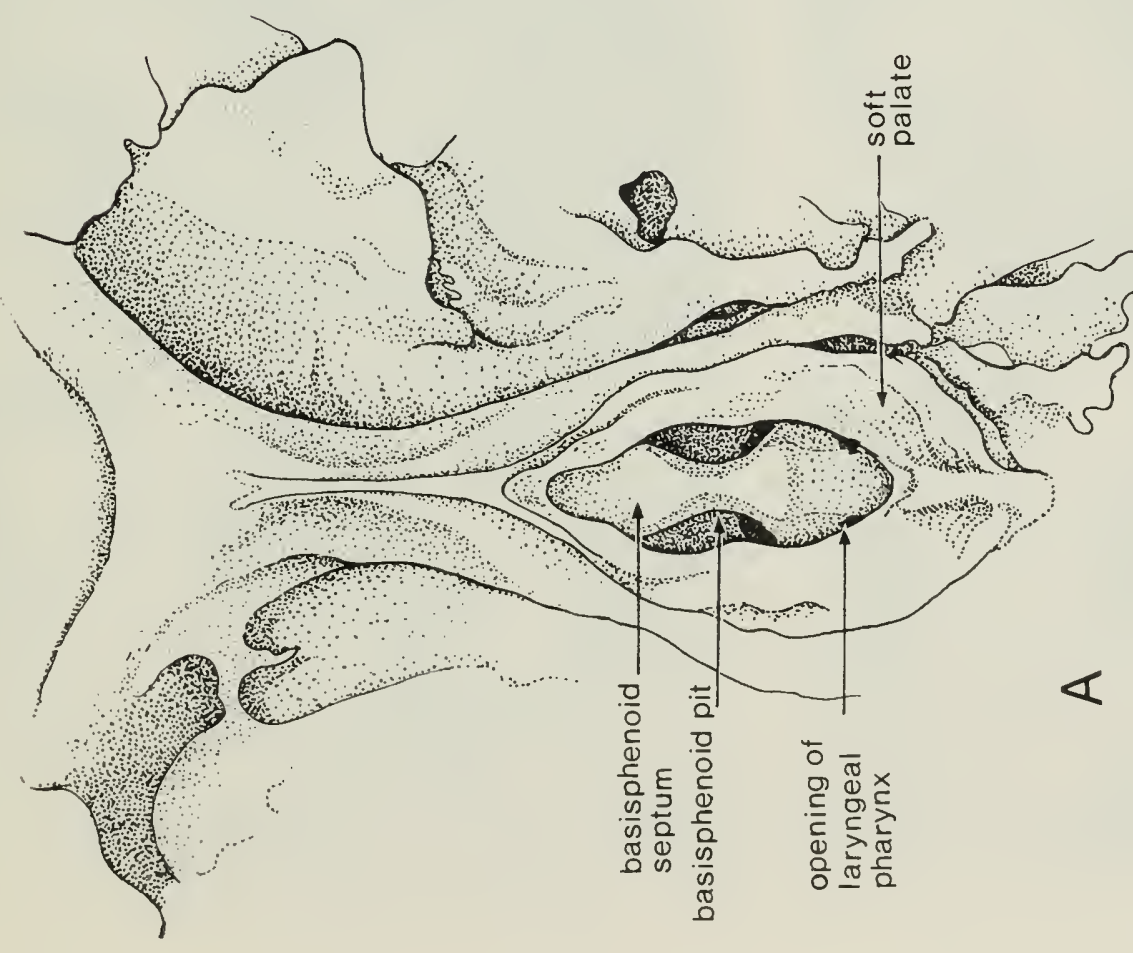



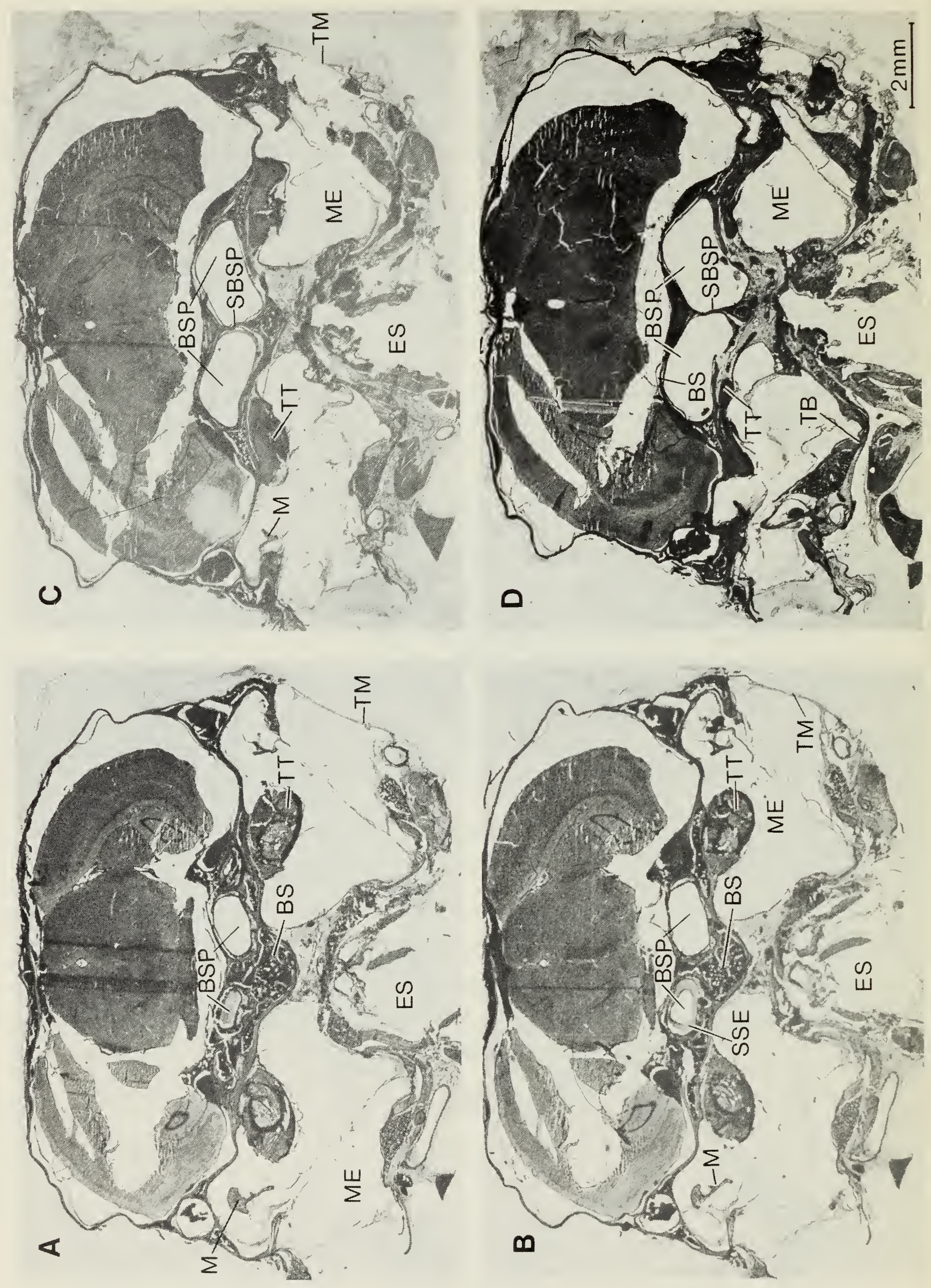
auditory tube and middle ear correspondingly differ from those structures in most other Microchiroptera, which have been characterized as being similar to those of such mammals as marsupials, insectivores, and some rodents (Henson, 1970). In Microchiroptera lacking basisphenoid pits, the air-filled, middle ear cavity communicates directly with the pharynx via the auditory tube, but in $O$. martienssen $i$ the auditory tube communicates with the pharynx via the lumen of the basisphenoid pits. Although emphasis has been placed on the morphology of the middle ear of bats by most researchers (see Henson, 1961, 1970), to our knowledge the connection of the middle ear cavity and the lumen of the basisphenoid pit by the auditory tube has not been previously documented.

Although Henson (1961) stated that the auditory tube in bats does not appear to be markedly different from that of other mammals, the tube is exceptionally large in $O$. martiensseni, and indeed is so in all bats that have been adequately studied (A. Pye, pers. comm.). In $O$. martiensseni it occupies most of the anterior space of the tympanic bone. Moreover, diverticula of the auditory tube were observed in $O$. martiensseni. These diverticula have been documented previously by Pye and Hinchcliffe (1968) in the phyllostomatid bat Chiroderma villosum and by Hinchcliffe and Pye (1969) in six other species of Microchiroptera.

In $O$. martiensseni the tympanic bone encloses most of the middle ear cavity and the posterior part of the auditory tube. It is large and terminates anteriorly in a lobular structure (as in Tadarida; Wassif, 1948) rather than in the styliform process that is characteristic of other Microchiroptera (Henson, 1970). The tensor tympani muscle, the mass of which correlates with body size, is well developed in Microchiroptera (Henson, 1970). The large size of this muscle in $O$. martiensseni is therefore not exceptional considering its function in preventing a significant amount of the pulse sound pressure from reaching the cochlea by contraction of this and the stapedius muscle (Henson, 1965).

In Otomops and other Microchiroptera orientation sounds are produced by the larynx (Griffin, 1958; Novick and Griffin, 1961). Ossification and fusion of cartilages have occurred, and the intrinsic muscles are well developed, especially the M. cricothyroideus, which applies tension to the vibrating membranes (Novick and Griffin, 1961). Moreover, the pinnae of some bats of the Molossidae are highly modified to receive high frequency signals (Henson, 1965). In O. martiensseni the external ear is exceptionally large, but unlike some other species of the family, in which the tragus is small or absent and the antiragus large (e.g., some species of Eumops and Tadarida), it lacks both structures. Although functions of the tragus and

Fig. 5 Representative photomicrographs (posterior to anterior) from $15 \mu \mathrm{m}$ serial sections through the posterior region of the basisphenoid pits of Otomops martiensseni ROM 66258, adult male. Haematoxylin-eosin stain. Distance of each section from the posterior end of the basisphenoid pits, expressed as a percentage of postero-anterior length (where 100 per cent is the most posterior): A 100 per cent, B 98 per cent, C 93 per cent, and D 86 per cent.

A Most posterior region of the basisphenoid pits (BSP). The posterior wall of the right pit contains loose connective tissue.

B Section slightly anterior to that of A. Proximity of basisphenoid pits (BSP) to middle ear cavity (ME) and tensor tympani muscle (TT) are illustrated.

C Increase in size of basisphenoid pits (BSP) and of tensor tympani muscle (TT).

D Increase in size of basisphenoid pits (BSP) and reduction in size of tensor tympani muscle (TT) and of middle ear cavity (ME). 

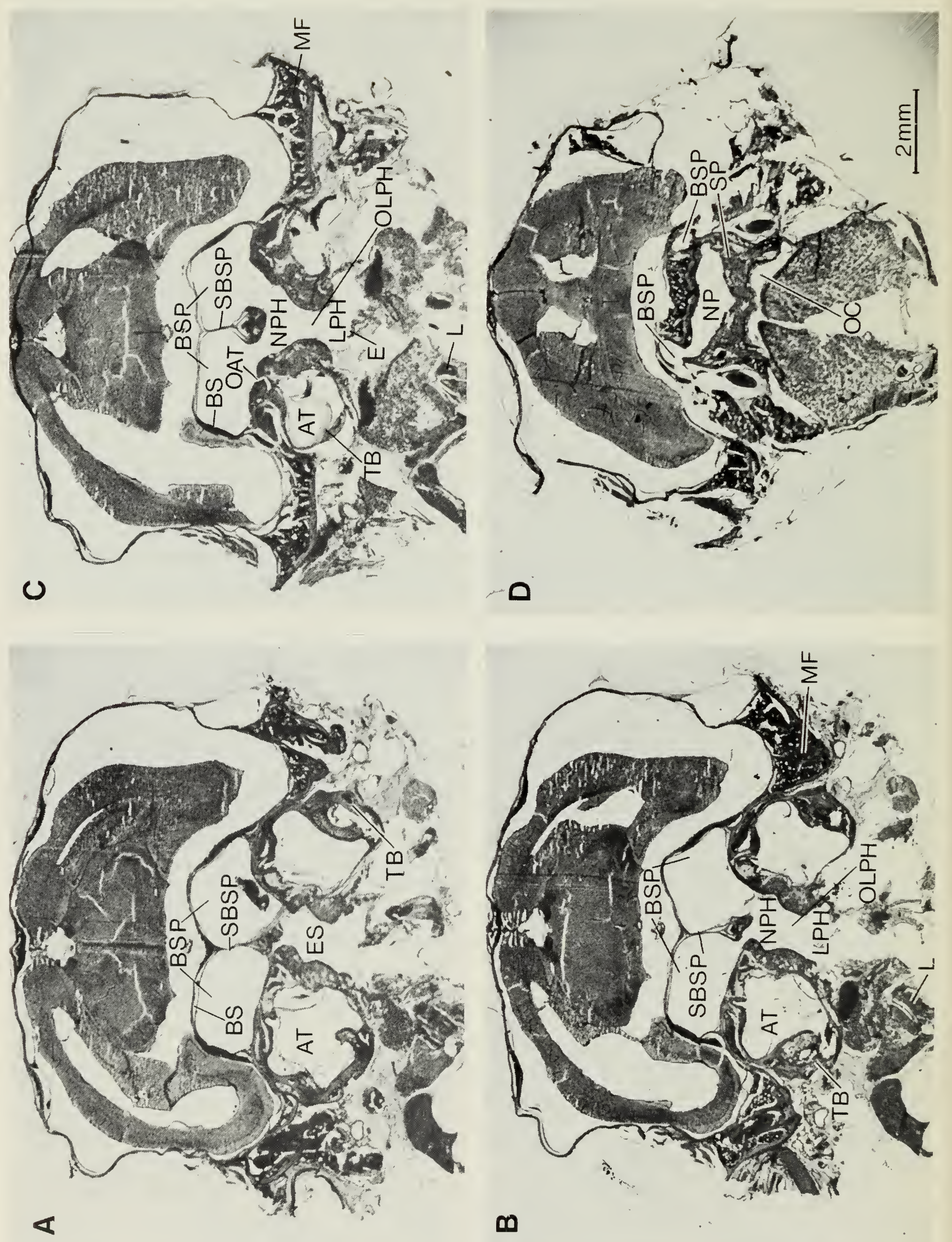
antitragus have been suggested (Henson, 1970), none has been substantiated. In Otomops the mobile lateral margin of the ear may be depressed, so that the ear becomes a funnel, and this change in position may be analogous in function to the tragus and antitragus. Alternately, the lateral margin of the external ear may act as a flap or a valve to close the meatus when intense sounds are presented to the ear, as in Mormoops (Wever and Vernon, 1961).

Correlated with the extreme development of the external ear in $O$. martiensseni is the large size of the middle ear, auditory tube, and tympanic bones; the last are thin and occupy much of the posteroventral part of the skull. The cochlea of this species is large relative to body size (Pye, 1973). Moreover, the basisphenoid pits are deep and well defined, and the close proximity of the opening of the laryngeal pharynx and the epiglottis may be significant, in that sound waves emitted from the larynx could be resonated in the pits before emission through the mouth cavity (or possibly through the nasal passages, although evidence from other molossids indicates oral emission; Gould, 1970).

Various aspects of echolocation in bats have been reviewed by Novick (1973, 1977), Simmons et al. (1975), and others. Most research has been based on studies of Microchiroptera other than bats of the family Molossidae. No experimental research has been conducted with bats of the genus Otomops (Pye, 1973), and only a few species of Tadarida and Molossus have been studied (Griffin and Novick, 1955; Henson, 1965, 1967; Pye, 1966), so that any interpretation of sonar mechanisms in $O$. martiensseni would be speculative, as bats of the Microchiroptera differ from family to family and even from species to species (Simmons, 1969). Moreover, the molossid bats studied to date appear to be flexible in their echolocating behaviour (Sales and Pye, 1974).

Although there is no experimental evidence, the possibility exists that basisphenoid pits may function as resonating chambers. Further research is needed to correlate the echolocating behaviour in Otomops and other molossid bats with peculiarities of structural design.

Fig. 6 Representative photomicrographs (posterior to anterior) from $15 \mu \mathrm{m}$ serial sections through middle and anterior regions of the basisphenoid pits of Otomops martiensseni ROM 66258, adult male. Haematoxylin-eosin stain. Distance of each section from the posterior end of the basisphenoid pits, expressed as a percentage of postero-anterior length (where 100 per cent is the most posterior): A 69 per cent, B 58 per cent, C 46 per cent, and D 12 per cent.

A Midregion of basisphenoid pits. Proximity of basisphenoid pits (BSP) and auditory tube (AT) are illustrated.

B Opening of lumen of basisphenoid pits (BSP) with nasal pharynx (NPH) and laryngeal pharynx (LPH).

C Opening of orifice of the auditory tube (OAT) into lumen of basisphenoid pits (BSP). Section demonstrates union of lumen of pits with pharynx and proximity of epiglottis $(E)$ and larynx (L).

D Reduction in size of basisphenoid pits (BSP) anteriorly. Only the pit on the right communicates with the nasal passage (NP), which is separated from the oral cavity (OC) by the soft palate (SP). 
We thank Mrs. Sophie Poray, Mr. Brian Herbert, and Mr. Anker Odum for illustrations; Mr. Cary Gilmour for laboratory assistance; Mr. James Borack and Mr. Leighton Warren for the photographs; Ms. Judy Eger and Mr. David Nagorsen for critical comments; and Mrs. Denise Machalski and Ms. Nancy Grepe for clerical and other assistance. We particularly thank Dr. Ade Pye for her helpful suggestions and criticisms of a previous draft of the manuscript. Acknowledgement is made for the use of facilities of the Laboratory of Analytical Systematics housed in the ROM and financed by a grant from the National Research Council of Canada to the Department of Zoology, University of Toronto.

This research represents part of a comprehensive bat research programme which is the result of the financial support to the second author from the National Research Council of Canada (Operating Grant A2385) and from the Royal Ontario Museum. 


\section{Summary}

The paired basisphenoid pits of Otomops martiensseni are large and deep, with overhanging edges which are pronounced posteriorly and posterolaterally. They are divided by a septum which is broad anteriorly but becomes narrow as it tapers posteriorly. The pits are deep posteriorly but become shallow towards the anterior margins. In a transverse plane the pits are located approximately midway between the foramen ovale and the mandibular fossa.

Histologically the basisphenoid pits are of cancellous bone; the ground substance is highly vascularized and is surrounded by a membrane of loose connective tissue. The arrangement and constitution of the tissues that line the pits internally do not differ from the normal mammalian histological pattern for the pharyngeal region.

The basisphenoid pits are partially covered by the soft palate and are located immediately dorsal to the opening of the larynx. The folds of the epiglottis are shaped to fit into the lips of the opening of the laryngeal pharynx, and the two structures are juxtaposed. The close proximity of the opening of the laryngeal pharynx and the epiglottis to the pits may be significant, in that sound waves emitted from the larynx could be resonated in the cavities of the pits before emission through the oral cavity. The pits communicate with the middle ear by way of the opening of the auditory tube.

\section{Sommaire}

Les fosses basisphénoïdaux d'Otomops martiensseni sont grosses et profondes avec des bords proéminents postérieurement et postérieurelatéralement. Elles sont separées par un septum qui est ample dans sa part antérieure mais qui est rétréci dans sa part postérieure. Les fosses sont profondes dans sa part postérieure et plus peu profondes dans sa part antérieure. Dans un plan latéral, les fosses sont localisées a mi-chemin entre le foramen ovale et la fosse mandibulaire.

Histologiquement, les fosses basisphénoïdaux sont osseuses et très vascularisées, et elles sont enturées par une membrane de tissu conjonctif. L'arrangement et la constitution des structures contiguës à les fosses basisphénoïdaux presentent le patron histologique normal de la région pharyngienne des mammifères.

Les fosses sont couvertes partiellement par le voile du palais et elles sont localisées en direction dorsale immédiate à l'ouverture du pharynx laryngien.

Cette ouverture est localisée dorsalement à l'épiglotte du larynx. La configuration des plis de l'épiglotte est modelée par s'ajustent à les lèvres de l'ouverture du pharynx laryngien et ces deux structures sont juxtaposées.

Anatomiquement, les fosses se communiquent avec l'oreille moyenne par le canal auditif.

La proximité si marquée de l'ouverture du pharynx laryngien et de l'épiglotte avec les fosses peut être ainsi significative parce que des ondes du son émises par le larynx peuvent être resonnées dans les cavités des fosses basisphénoïdaux avant l'émission du son par la cavité buccale. 


\section{Literature Cited}

ANDERSON, $\mathrm{S}$

1972 Two semiautomatic systems for linear measurement. Curator 15:220-228.

FIORE, M. S. H. DI

1963 An atlas of human histology. 2nd ed. Philadelphia, Lea and Febiger. 224 pp.

GOULD, E.

1970 Echolocation and communication in bats. In Slaughter, B. H. and D. W. Walton, eds., About bats. Dallas, Southern Methodist University Press, pp. 144-161.

GRIFFIN, D. R.

1958 Listening in the dark. New Haven, Yale University Press. 413 pp.

GRIFFIN, D. R. and A. NOVICK

1955 Acoustic orientation of neotropical bats. Journal of Experimental Zoology 130:251-300.

HENSON, O. W., Jr.

1961 Some morphological and functional aspects of certain structures of the middle ear in bats and insectivores. University of Kansas Science Bulletin 43:151-255.

1965 The activity and function of middle-ear muscles in echo-locating bats. Journal of Physiology 180:871-887.

1967 Auditory sensitivity in Molossidae (Chiroptera). Anatomical Record 157:363-364. [Abstract]

1970 The ear and audition. In Wimsatt, W. A., ed., Biology of bats. New York, Academic Press, vol 2, pp. 181-263.

HILL, J. E. and P. MORRIS

1971 Bats from Ethiopia collected by the Great Abbai Expedition, 1968. Bulletin of the British Museum (Natural History) Zoology $21: 25-49$.

HINCHCLIFFE, R. and A. PYE

1969 Variations in the middle ear of the Mammalia. Joumal of Zoology 157:277-288.

LARGEN, M. J., D. KOCK, and D. W. YALDEN

1974 Catalog of the mammals of Ethiopia. I: Chiroptera. Monitore Zoologico Italiano, Supple. 5 (16):221-298.

LUNA, L. G., ed.

1968 Manual of histologic staining methods of the Armed Forces Institute of Pathology. 3rd ed. New York, McGraw-Hill. 258 pp.

MEESTER, J. and H. W. SETZER, eds.

1971 The mammals of Africa: an identification manual. Part two; Order Chiroptera. Washington, D. C., Smithsonian Institution Press. 73 pp.

MILLER, G. S.

1907 The families and genera of bats. United States National Museum Bulletin 57:1-28.

MILLER, M. E.

1962 Guide to the dissection of the dog. 3rd ed. Ann Arbor, Edwards Brothers. 368 pp.

NOVICK, A.

1973 Echolocation in bats: a zoologist's view. Journal of the Acoustical Society of America 54:139-146.

1977 Acoustic orientation. In Wimsatt, W. A., ed., Biology of bats. New York, Academic Press, vol. 3, pp. 73-287. 
NOVICK, A. and D. R. GRIFFIN

1961 Laryngeal mechanisms in bats for the production of orientation sounds. Journal of Experimental Zoology 148:125-146.

PETERSON, R. L.

1965 A review of the flat-headed bats of the family Molossidae from South America and Africa. Royal Ontario Museum, Life Sciences Contributions 64:1-32.

1969 Further notes on the African molossid bat Tadarida aloysiisabandiae. Los Angeles County Museum, Contributions in Science 161:1-6.

PYE, A.

1966 The structure of the cochlea in Chiroptera. II. The Megachiroptera and Vespertilionoidea of the Microchiroptera. Journal of Morphology 119:101-120.

1973 The structure of the cochlea in Chiroptera from Africa. Periodicum Biologorum 75:83-87.

PYE, A. and R. HINCHCLIFFE

1968 Structural variations in the mammalian middle ear. Medical and Biological Illustration $18: 122-127$.

SALES, G, and D. PYE

1974 Ultrasonic communication by animals. London, Chapman and Hall. 281 pp.

SIMMONS, J. A.

1969 Acoustic radiation patterns for the echolocating bats Chilonvcteris rubiginosa and Eptesicus fuscus. Journal of the Acoustical Society of America, pt. 2, 46:1054-1056.

SIMMONS, J. A., D. J. HOWELL, and N. SUGA

1975 Information content of bat sonar echoes. American Scientist 63:204-215.

SOKAL, R. R. and F. J. ROHLF

1969 Biometry; the principles and practice of statistics in biological research. San Francisco, W. H. Freeman. $776 \mathrm{pp}$.

WALKER, E. P

1975 Mammals of the world. 3rd ed. Baltimore, Johns Hopkins Press. 2 vols.

WASSIF, $\mathrm{K}$.

1948 Studies on the structure of the auditory ossicles and tympanic bone in Egyptian Insectivora, Chiroptera and Rodentia. Fouad I University Bulletin, Faculty of Science, 27:177-213.

WEVER, E. G. and J. A. VERNON

1961 The protective mechanisms of the bat's ear. Annals of Otology, Rhinology, and Laryngology $70: 1-13$. 

ISBN 0-88854-238-0

ISSN 0384-8159 